\title{
Analysis on the Current Situation of Wuhan Cross-border E-commerce Talent Training
}

\author{
Xiaowei Zhu ${ }^{1,2, a}$ and Hao Ming \\ ${ }^{1}$ Wuhan Technology and Business University, China, HuBei, Wuhan, 430065 \\ ${ }^{2}$ Hubei Business Service Development Research Center, China, HuBei, Wuhan, 430065 \\ a81892036@qq.com
}

Keywords: Wuhan; Cross-border e-commerce; Talent training

\begin{abstract}
With the rapid development of cross-border e-commerce industry, the demand for crossborder e-commerce talents is increasing. In order to meet this demand, we need to cultivate more high-quality talents of cross-border e-commerce. This paper, based on the current situation of Wuhan universities and cross-border e-commerce enterprises, analyzes the problems in the training process of cross-border e-commerce talents and puts forward corresponding suggestions, hoping to provide reference for the training of cross-border e-commerce talents in China.
\end{abstract}

\section{The Status of Cross-border E-commerce Talent Demand in China}

The year 2018 is the crucial year for the successful completion of a well-to-do society. In terms of foreign trade, the threshold for cross-border e-commerce models and the reduction in the cost of foreign trade make small and medium-size enterprises face a large number of business opportunities. Hubei plans to launch the "Internet plus Poverty Alleviation" campaign in the next three years, step up e-business poverty alleviation, and continue to develop e-commerce poverty-reduction model villages. E-commerce poverty alleviation should be developed and talent support is the key. According to incomplete statistics, the talent gap in the relative field of cross-border e-commerce in China is approximately 4.5 million. In 2017, this number increased by $39 \%$. Graduates from domestic universities also have shortcomings such as lack of solid professional knowledge, limited vision, narrow knowledge, and outdated knowledge.

The whole process of cross-border e-commerce needs the coordination of supply procurement, logistics and transportation, and after-sales service. Any problems in any link may affect the development of cross-border e-commerce. The following three issues are summarized: The first is the operational problem. Talents are needed to expand the foreign trade market to find a reliable source of goods, and relevant talents need to be able to effectively promote overseas markets. The second is the logistics issue. Today's logistics model is at the bottleneck stage, subject to constraints such as transportation methods and logistics management personnel. Cross-border e-commerce information management requires a large number of people who are familiar with related technologies. The third is the after-sales problem. The important point of cross-border e-commerce compared to domestic e-commerce is that it is difficult to establish a mature overseas after-sales service team. The gap in talents limits the development of cross-border e-commerce.

\section{Analysis on the Talent Training of Cross-border E-commerce in Wuhan}

The Status of Cross-Border E-Commerce Talent Training in Wuhan. If traditional small and medium-sized foreign trade enterprises want to transform their cross-border e-commerce enterprises, they will need comprehensive talents with international trade knowledge and e-commerce professional skills. A single professional talent cannot meet the needs of enterprises. According to incomplete statistics, there are about 300 cross-border e-commerce companies in Wuhan and about 40,000 cross-border electricity merchants. The current talent shortage in this area is still 50,000, and this figure is still increasing year by year. There are about 100,000 potential talents in e-commerce, international trade and English that are still being cultivated in major universities and colleges in 
Wuhan. Cross-border e-commerce is still in its early stages of development. Talents are mainly cultivated by schools and enterprises. The school has cultivated a focus on theoretical knowledge, and has not perfected the training of practical abilities. The cultivation of companies also has the limitation of the foreign language level of the talents themselves, which has led to the current training of cross-border electric businessmen who are unable to fully meet the needs of companies. It is difficult for enterprises to recruit qualified personnel from schools. This has to some extent constrained the development of cross-border e-commerce in Wuhan. However, with the exploration of the past few years, it has gradually explored ways to cultivate talents through cooperation between schools and enterprises. For example, "his partner" will develop cross-border electricity merchants in this way. Lecturers will teach students and make them be able to directly enter companies after mastering theoretical knowledge.

New Features of Cross-Border E-Commerce Compared to Traditional International Trade Talents. The development opportunities brought about by the emergence of cross-border ecommerce have led many traditional small and medium-sized foreign trade companies to transform their cross-border e-commerce enterprises. The inadequacy of talent capacity in enterprises will become the main factor restricting the transition. The combination of e-commerce and international trade has brought new features to the demand for talents. Cross-border electricity traders are better than traditional international traders and domestic electricity traders to emphasize differences. The first point is that cross-border traders need to have foreign language ability to communicate on the network. Cross-border e-commerce has great demand for the foreign language of relevant practitioners. Having a certain level of English proficiency is the most basic requirement for crossborder e-commerce professionals. The second point is that cross-border traders need to be familiar with the cross-border e-commerce platform. The use of a network platform to operate a management company requires the company to have personnel who are familiar with the use of the corresponding platform rules. The third point is that cross-border traders need to skillfully use computer technology. Today, the workflow of commodity inspection and insurance, which are closely related to logistics, has become more streamlined, standardized, and information-based. This requires cross-border power traders to use the network for information processing and supervision of the entire foreign trade process. The fourth point is that cross-border electricity providers need to be familiar with the network environment. Employees need to be familiar with the cross-border network environment. Relevant talents must have good information collection capabilities and information processing and analysis capabilities. The use of network promotion tools is the key to online marketing.

\section{Problems in the Training of Cross-border E-Commerce Talents in Wuhan}

Problems of Cross-Border E-Commerce Course Arrangement in Universities. Cross-border electricity merchants need a composite specialty that combines e-commerce and international trade to cultivate comprehensive capabilities. Colleges and universities are the major training grounds for cross-border electricity merchants. Currently, there are two general courses offered: e-commerce and international trade. In the e-commerce profession, the degree of emphasis of the curriculum arrangement on foreign languages is not high enough, resulting in the later development of crossborder e-commerce talents will fall in foreign language capabilities. The practice course arrangement will generally use Taobao as a case. The lack of practical experience in the crossborder e-commerce platform such as Amazon leads to a lack of awareness of talents on the crossborder e-commerce platform. In the application of intelligent management system, only a preliminary understanding of the logistics management simulation platform, lack of in-depth understanding of the overseas warehouse system. Students will need to learn cross-border logistics knowledge after employment or entrepreneurship in the future, and the time for personnel training will be delayed.

Cross-Border E-Commerce Teachers in Colleges and Universities. As cross-border ecommerce is a new high-speed professional, knowledge and skills are updated very quickly. 
Therefore, three problems will arise in teacher education. The first is that teachers' theoretical knowledge is not comprehensive. Nowadays, teachers of cross-border e-commerce professional are generally served by teachers in international trade, business English and e-commerce. Many teachers fail to master comprehensive cross-border e-commerce knowledge. Therefore, the cultivated talents do not have enough theoretical knowledge to meet the needs of cross-border companies. The second is the lack of practical experience. Many teachers used to work in ecommerce. However, the exploration experience in the field of cross-border e-commerce is not sufficient. It is difficult to train people with actual combat ability based on their own experience. The third is that the teaching effect is not good, the cross-border e-commerce related theoretical knowledge is updated quickly, teachers have not yet mastered the new knowledge to teach students, teaching results will be difficult to achieve the goal. In order to enhance the effectiveness of training cross-border e-commerce talents, the cross-border e-commerce teachers in universities need to be further improved.

Cooperation between Universities and Enterprises. Universities in the field of cross-border ecommerce can hardly cultivate talents that are satisfactory to the enterprises. Cross-border electricity merchants graduate to general entrepreneurship or employment after graduation. Therefore, cooperation between universities and enterprises is very important. Many schools nowadays have trained talents by cooperating with companies in running schools or internships. According to the survey, most of the school-enterprise cooperation has not achieved the desired results. The enterprises have invested less in the process of talent cultivation and school-enterprise cooperation is still in its infancy. The training of cross-border e-commerce talents requires all aspects to enhance the effectiveness of education, and deeper cooperation requires the efforts of universities and enterprises.

\section{Recommendations for Training Cross-border E-Commerce Talents in Wuhan}

Formulating and Improving a Cross-Border E-Commerce Talent Training Program. According to the query of the human resource network, the current positions of cross-border ecommerce companies are: cross-border e-commerce customer service, cross-border e-commerce sales, cross-border e-commerce product developers, and cross-border e-commerce foreign language editing/translation/copywriting/copywriting, warehousing and logistics division, web designer/artist, cross-border payment specialist, customs broker, equipment technician, cross-border e-commerce business manager, cross-border e-commerce operations director, etc. The cross-border e-commerce job talents are divided into three categories: business talents, professional talents and management talents. Cross-border e-commerce consumer groups come from all over the world, so business talents need to have strong English (small language) capabilities; have the ability to use foreign languages to analyze cross-border e-commerce business problems; master the basic operations of computers and platform software. Professional talents need to master office software; master professional software such as Photo shop and $\mathrm{Au}$; familiar with platform functions such as store management, store promotion, information management, and order management. Managerial talents need to have good thinking ability, communication skills, practical work attitude, good psychological quality and ability to resist stress, and have teamwork awareness and service spirit.

Emphasizing the Training of Cross-Border E-Commerce Talents. Cross-border e-commerce capabilities can be taught in stages, integrating theory and practice, and improving the overall capabilities of talents. The following three steps are recommended for training:

The first step is the development of basic skills. In order to meet the requirements of enterprises, the talents are roughly divided into the following capabilities: cognitive ability, analytical ability, platform application ability, transaction negotiation ability, foreign language ability, and computer technology ability. In the first two semesters of the university, the necessary knowledge of crossborder e-commerce can be inserted into existing courses such as Introduction to E-commerce, International Trade Practices, Cross-border E-commerce Laws and Regulations, Consumer Behavior, Business English, and Computer Foundation. Theoretical knowledge, through the way of 
classroom inspections, urges students to learn progress and lays a good foundation for mastering professional skills.

Greatly Strengthening the Construction of Teachers' Strength. Cross-border e-commerce professional teachers need to have English proficiency and master international trade knowledge and e-commerce related knowledge. Schools should pay attention to the internal training of teachers and the introduction of external teacher resources, referred to as "internal training and external guidance." In response to the existing faculty resources, training is conducted according to the areas of incompetence, so that teachers can meet the demand of cross-border e-commerce for the comprehensive capabilities of talents and effectively teach students. The introduction of teachers can come from managers of first-tier cross-border e-commerce companies or excellent project managers. Colleges and universities need to tap into multiple channels, and introduce well-known domestic enterprises such as Alibaba, Tencent and Jingdong into the campus to customize talents. Through written interviews and other methods, the selected students are handed to practical instructors and project managers to create a talent development process that matches "theoretical teaching+skills teaching+project outsourcing teaching+corporate practice+self-employment (entrepreneurship)". Students interact seamlessly with society to meet the ever-changing needs of companies for cross-border e-commerce talent.

Promoting Deep Cooperation between Universities and Enterprises. According to statistics, currently Wuhan universities provide students with platform practical lessons in the teaching of cross-border e-commerce. However, the practice platform is not closely related to the actual work, making the practice platform only help teachers' teaching work but not practical improve student software application capabilities and platform operational capabilities. In the teaching of crossborder e-commerce, colleges and universities can practice the platform to allow students to master the knowledge of theoretical lessons in their operations. Students can familiarize themselves with major cross-border e-commerce software on the operating platform, so that they can have a reference on how to choose according to the company's situation in the future. At present, the practice platform provided by the school for students is generally some domestic software. The training platform is relatively single and cannot improve the overall quality through practical training. Cognitive skills, analytical skills, and application capabilities of the platform are difficult for students to master. When students enter a job position in a cross-border e-commerce company, they still need to learn from basic software operations. This slows down the development of crossborder e-commerce talents.

\section{Acknowledgement}

Fund Project: MOE (Ministry of Education in China) Project of Humanities and Social Sciences (Project No.14YJCZH154)

Funding team: Wuhan Technology and Business University Academic Team (Project No. XSTD2015004)

\section{References}

[1] Yulan Zhan: Analysis of the Core Positions and Skills Requirements of Cross Border ECommerce Talents and Countermeasures -- Based on the Perspective of International Trade Major of Higher Vocational Education[J], China Market, 2018(02):148-149.

[2] Yi Su: China's Cross Border E-Commerce Logistics Development Status and Talent Education Countermeasures[J], Asia Pacific Education, 2016(36):279-279.

[3] Jiangqiao Mei: Research on Demand Characteristics of Cross-Border E-Commerce Talents[J], Management Observer, 2014(31):119-120.

[4] Hongjing Lv: Research on Talents Training Mode of Cross Border E-Commerce in Higher Vocational E-commerce Specialty[J], Electronic Commerce, 2015(11):74-75. 
[5] Shihai Xu: Research on the Necessity and Countermeasures of Cross Border E-Commerce Talents Training[J], Journal of Hubei University of Economics(Humanity and Social Science Edition), 2016, 13(10):76-77.

[6] Jin Li: Problems and Suggestions in the Teaching Process of Cross Border E-Commerce Practice[J], Modern Economic Information, 2016(17):439.

[7] Liao Zheng: Research on Training Mode of International Trade Professionals in Higher Vocational Colleges Based on Cross Border E-Commerce[J], Economic \& Trade, 2016(13):129.

[8] Shujuan Gao and Na Dong: Demand Analysis and Training Countermeasures of Cross Border E-Commerce Talents[J], Fortune Today(China Intellectual Property), 2017(03):59.

[9] Xiaolan Zhuang: Demand Analysis and Training Strategies for Core Talents of Cross Border ECommerce[J], Management Observer, 2015(17):178-180. 